\title{
POLITIČKA PRAVA U KRALJEVINI SRBA, HRVATA I SLOVENACA: RAZVOJ TEMELJNIH OBILJEŽJA
}

Sažetak: $\quad U$ radu se razmatra razvoj temeljnih obilježja političkih prava u Kraljevini Srba, Hrvata i Slovenaca u vremenu od nastanka države do proglašenja Šestosiječanjske diktature 1929. godine. Autori kao temeljna obilježja političkih prava u prvim godinama Kraljevine SHS detektiraju značajnu prisutnost nacionalnog kriterija pri definiranju ovlaštenika političkih prava, zatim nejednakost državljana $u$ pogledu biračkog prava, autoritarnost vlasti u reguliranju, ali i mogućnostima ostvarenja političkih prava te partikularizam u uređenju političkih prava. Autori nadalje analiziraju odnos Ustava prema temeljnim obilježjima političkih prava te argumentiraju tezu da su usprkos odredbama Ustava, osnovne smjernice razvoja političkih prava prisutne u predustavnom razdoblju, bile u značajnoj mjeri vidljive i kasnije.

Ključne riječi: $\quad$ politička prava, biračko pravo, Kraljevina SHS, Zakon o zaštiti države

\section{UVOD}

Predmet rada je razvoj političkih prava u Kraljevini Srba, Hrvata i Slovenaca (dalje u radu: Kraljevini SHS) u vremenu od nastanka države 1. prosinca 1918. godine pa sve do proglašenja Šestosiječanjske diktature 1929. godine. ${ }^{1}$ Pod političkim pravima mislimo na prava građana

Dr. sc. Ivan Kosnica, docent na Katedri za povijest hrvatskog prava i države, Pravni fakultet, Sveučilište u Zagrebu, Ćirilometodska 4, 10000 Zagreb, Republika Hrvatska. Adresa e-pošte: ikosnica@pravo.hr ORCID: https://orcid.org/0000-0002-0467-6062

** Martina Protega, mag. iur, Ured javnog bilježnika Božo Miletić, Grge Tuškana 39, 10000 Zagreb, Republika Hrvatska. Adresa e-pošte: martina.protega@gmail.com ORCID: https://orcid.org/0000-0002-6892-4301

1 Ovdje napominjemo da je u službenim aktima u razdoblju od nastanka države 1. prosinca 1918. godine pa sve do donošenja Vidovdanskog ustava 28. lipnja 1921. godine država nazivana i „Kraljevstvo Srba, Hrvata i Slovenaca“. Naziv „Kraljevina Srba, Hrvata i Slovenaca" ustalio se tek od donošenja Ustava 1921. godine u kojem je izrijekom navedeno da je službeni naziv države „Kraljevina Srba, Hrvata i Slovenaca“ (čl. 1. st. 2. Ustava Kraljevine SHS). Ustav Kraljevine Srba, Hrvata i Slovenaca 
„kojima je smisao i svrha da građanima osiguraju aktivno sudjelovanje u obnašanju i legitimiranju vlasti“" ili kako ih definira T. H. Marshall riječ je o vrsti prava građana kojima je zajedničko obilježje da omogućavaju građanima „sudjelovanje u izvršavanju političke vlasti“. ${ }^{3}$ Pri tome su najznačajnija politička prava biračko pravo, pravo na političko udruživanje, pravo na javno okupljanje i sloboda tiska. ${ }^{4}$

Cilj rada je sagledavanje političkih prava u cjelini, a sve radi utvrđivanja temeljnih obilježja razvoja političkih prava u Kraljevini SHS. Teorijsko uporište za ovakav pristup vidimo u djelu T. H. Mashalla Citizenship and Social Class u kojem Marshall analizira politička prava upravo koristeći takav integralni pristup. Pri tome Marshall politička prava označava terminom political citizenship..$^{5}$ Osim Marshalla, i neki drugi autori koji se bave političkim pravima označavaju ta prava zbirnim terminom political citizenship te tako jasno razlikuju taj koncept od koncepta državljanstva kao vida formalne pripadnosti osobe državi. Tako primjerice Andreas Fahrmeir $\mathrm{u}$ knjizi Citizenship: The Rise and Fall of a Modern Concept jasno razlikuje formalnu pripadnost osobe državi koju označava terminom formal citzenship, od kruga osoba koje u pojedinoj zemlji imaju politička prava, odnosno political citizenship. Pri tome Fahrmeir ističe da se krug državljana i krug osoba s političkim pravima posve ne poklapaju. ${ }^{6} \mathrm{O}$ konceptulanim razlikama između termina citizenship shvaćenog kao status (citizenship as status) i termina citizenshipa shvaćenog kao osnove prava (citizenship as rights) raspravlja i Christian Joppke te pri tome upućuje na nužnost razlikovanja ova dva značenja pojma citizenship. ${ }^{7}$ Razlika između ta dva koncepta vidljiva je i u pravnoj terminologiji primjerice njemačkog jezika. Tako u njemačkom jeziku postoji značajna razlika između termina Staatsangehörigkeit koji označava formalnu pripadnost osobe državi i termina Staatsbürgerschaft što bismo mogli prevesti na način da se radi o osobama koje u pojedinoj državi uživaju politička prava. ${ }^{8} \mathrm{U}$ hrvatskoj pravnoj tradiciji za označavanje formalne veze između osobe i države koristimo naziv državljanstvo, dok bi najbliži ekvivalent terminu political citizenship po našem mišljenju bila sintagma ovlaštenici političkih prava. ${ }^{9}$

Cilj je rada utvrditi temeljna obilježja te razvoj političkih prava u Kraljevini SHS, dakle onog što se u engleskoj terminologiji označava terminom political citizenship. Prednosti korištenja integralnog pristupa u izučavanju političkih prava vidimo u tome što takav pristup

(Obnarodovan u br. 142a „Službenih Novina“ na Vidovdan 28. lipnja 1921. god. u Beogradu), Državna štamparija Kraljevine Srba, Hrvata i Slovenaca, Beograd, 1926.

2 Pezo, V., (ur.) Pravni leksikon, Leksikografski zavod „Miroslav Krleža“, Zagreb, 2007, str. 1103.

3 Marshall, T. H. Class, Citizenship and Social Development, Doubleday and Company, Anchor Books. New York, 1965, str. 78.

4 Pezo, op. cit. u bilj. 2, str. 1103-1104.

5 Marshall, op. cit. u bilj. 3, str. 78.

6 Fahrmeir, A., Citizenship: The Rise and Fall of a Modern Concept, Yale University Press, New Haven and London, 2007, str. 2-3.

7 Napominjemo da Joppke osim državljanstva kao statusa (citizenship as status) i državljanstva kao osnove prava (citizenship as rights) upućuje in na nužnost razlikovanja treće dimenzije koncepta državljanstva koja se ogleda u vezi između državljanstva i identiteta (citizenship as identity). Joppke, C., Transformation of Citizenship: Status, Rights, Identity, Citizenship Studies, vol. 11, no. 1,2007 , str. 38 .

8 O razlici između ovih dvaju termina vidi: Bös, M., The Legal Construction of Membership: Nationality Law in Germany and the United States, Program of the Study of Germany and Europe. Working Paper Series No. 00.5, str. 5-7, dostupno na: http://aei.pitt. edu/63702/1/PSGE_00_5.pdf (pristup: 09. 12. 2018.)

9 Na problem nedovoljno razvijene terminologije u hrvatskom jeziku te poteškoće u prevođenju engleskog termina citizenship, kao i na višeznačnost tog termina upućuje Milan Mesić. Pri tome on za označavanje državljanstva kao osnove građanskih, političkih i socijalnih prava koristi kovanicu „građansko-državljanska prava“, odnosno „građansko državljanstvo“ ili „državljansko građanstvo“. Mesić, M., Globalizacija i građansko-državljanska prava, Politička misao, god. 45, br. 1, 2008, str. 73. 
pruža temelj za kompleksnije i dublje sagledavanje dinamike razvoja političke zajednice u Kraljevini SHS.

Strukturalno gledano, rad smo podijelili u tri dijela. U prvom dijelu analiziraju se temeljna obilježja razvoja političkih prava u razdoblju do donošenja Vidovdanskog ustava. U sklopu ovog dijela obrađujemo nacionalnu pripadnost kao temelj političkih prava, zatim problematiku nejednakosti birača, autoritarnost vlasti u odnosu prema političkim pravima građana te fragmentarnost uređenja političkih prava. U drugom dijelu rada analiziraju se temeljna obilježja političkih prava u Vidovdanskom ustavu. U sklopu ovog dijela rada analizira se odnos Ustava prema nacionalnoj pripadnosti kao temelju političkih prava, zatim problem nejednakosti državljana u pogledu uživanja političkih prava, naglašava se liberalan karakter Ustava te činjenica da je Ustavom propisana lista političkih prava koja je uključivala i neke specijalne odredbe čime je postignut minimalan stupanj unifikacije. U trećem dijelu rada analizira se razvoj političkih prava u razdoblju važenja Vidovdanskog ustava. Cilj ovog dijela rada jest dati odgovor na pitanje u kojoj su mjeri temeljne odrednice razvoja, vidljive u razdoblju do donošenja Vidovdanskog ustava, bile prisutne i kasnije.

\section{TEMELJNA OBILJEŽJA RAZVOJA POLITIČKIH PRAVA U RAZDOBLJU DO DONOŠENJA VIDOVDANSKOG USTAVA}

\subsection{NACIONALNA PRIPADNOST I POLITIČKA PRAVA}

Nacionalna pripadnost državljana kao osnova političkih prava došla je do izražaja još za vrijeme Države SHS u naputku Narodnog vijeća u kojem je ono odredilo da članovi mjesnih odbora mogu biti Slovenci, Hrvati i Srbi i ostali Slaveni dok članovi tih odbora ne mogu biti Nijemci i Mađari. ${ }^{10}$ Bilo je to odraz sve češće primjene nacionalnog kriterija, koja je bila prisutna u upravnoj praksi i za vrijeme Prvog svjetskog rata, a pred sam kraj rata je dodatno dobila na značaju. ${ }^{11}$

Nacionalno definiranje ovlaštenika političkih prava bilo je prisutno i u prvim godinama Kraljevine SHS. Vidljivo je to na primjeru formiranja Privremenog narodnog predstavništva Kraljevine SHS tijekom 1919. godine budući da je tad korišten nacionalni kriterij prilikom izbora članova toga tijela. Tako su primjerice od predstavnika Baranje, Bačke i Banata u Privremeno narodno predstavništvo ušla 24 zastupnika od kojih su 19 bili Srbi, 4 Hrvati te jedan Slovak. Od ostalih neslavenskih grupa u sastav Privremenog narodnog predstavništva nije ušao nitko, iako su na tom području značajne etničke grupe bili Mađari, Nijemci, pa i Rumunji, a slavensko stanovništvo je činilo tek relativnu većinu. ${ }^{12}$

10 Goldstein, I., Hrvatska 1918.-2008, EPH Liber, Zagreb, 2008, str. 20.

11 Primjena nacionalnog kriterija u postupanju upravnih vlasti u Austro-Ugarskoj Monarhiji bila je vidljiva primjerice u internacijama vlastitih državljana provođenim tijekom Prvog svjetskog rata. Vidi više u: Budisavljević, S., Stvaranje države Srba, Hrvata i Slovenaca: povodom četrdesetgodišnjice jugoslavenskog ujedinjenja, Jugoslavenska akademija znanosti i umjetnosti, Zagreb, 1958, str. 11-21.

12 Podatci prema: Bara, M., Trianon, podjela svjetova i bačko-baranjski Hrvati, Povećalo: časopis za povijest i prosudbe o povijesnoj zbilji, sv. 4-7, 2012, str. 35-36; O izboru slovačkog predstavnika vidi: Janjetović, Z., Deca careva, pastorčad kraljeva: Nacionalne 
„Logiku“ definiranja političkih prava na temelju nacionalne, a ne nužno državljanske pripadnosti slijedio je i Zakon o izboru narodnih poslanika za Ustavotvornu skupštinu iz 1920. godine. Tako, članak 9. toga zakona tek načelno određuje da biračko pravo imaju muški državljani stariji od 21 godine, dok na praktičnoj razini umanjuje značaj državljanstva kao osnove biračkog prava na način da biračko pravo daje i svim Slavenima koji su se nastanili u zemlji bez obzira na njihovo državljanstvo, dok to pravo ne daje državljanima s pravom opcije. ${ }^{13}$ Takvom odredbom zakona, nositelji političkih prava definirani su u određenoj mjeri neodređeno budući da se u praksi prilikom sastavljanja popisa birača moglo postaviti pitanje procjenjivanja nečije slavenske, odnosno neslavenske pripadnosti. ${ }^{14}$ Druga razina problema manifestirala se u nepostojanju provedbenih propisa kojima bi detaljno bio uređen institut opcije. ${ }^{15}$

Specifično uređenje biračkog prava na izborima za Ustavotvornu skupštinu 1920. godine dovelo je do toga da su na tim izborima glasovali primjerice Česi i Slovaci upisani u popise birača, iako nisu bili državljani Kraljevine SHS, dok je pravo glasa bilo uskraćeno brojnim Židovima, Mađarima i Nijemcima. ${ }^{16}$ Etničko definiranje ovlaštenika biračkog prava kao temeljnog političkog prava značajno je utjecalo i na mogućnost uživanja drugih političkih prava. U takvim okolnostima velikom broju Židova, Mađara i Nijemaca bilo je de facto ograničeno i pravo na javno okupljanje te pravo na političko udruživanje. ${ }^{17}$ Suprotno tome, Česi i Slovaci su iskoristili pravo na političko udruživanje te su osnovali svoje stranke. ${ }^{18}$ Pored njih, stranački su se organizirali i Albanci i Turci, za koje nije bilo predviđeno pravo opcije, u stranku Džemijet te su s tom strankom i sudjelovali na izborima za Ustavotvornu skupštinu. ${ }^{19}$

manjine u Jugoslaviji, INIS, Beograd, 2005, str. 172.

13 Usp. čl 9. Zakona o izboru narodnih poslanika za Ustavotvornu skupštinu. Zakon o izboru narodnih poslanika za ustavotvornu skupštinu Kraljevine Srba, Hrvata i Slovenaca, Naklada štamparije jugoslavenskog kompasa, Zagreb, 1920.; O članku 9. toga zakona vidi i: Polić, L., O pravnim osnovima budućeg izbornoga reda, Mjesečnik: glasilo pravničkoga društva, Zagreb, br. 2, 1922, str. 51; Matijević, Z., U sjeni dvaju orlova: Prilozi crkveno-nacionalnoj povijesti Hrvata u prvim desetljećima 20. stoljeća, Golden marketing-Tehnička knjiga, Zagreb, 2005, str. 101-113; Gligorijević, B., Parlament i političke stranke u Jugoslaviji (1919-1929), Institut za suvremenu historiju, Narodna knjiga, Beograd, 1979, str. 70.; Kosnica, I., Definiranje državljanskog korpusa na hrvatsko-slavonskom području u Kraljevini SHS/Jugoslaviji, Zbornik Pravnog fakulteta Sveučilišta u Rijeci, vol. 39, br. 2, 2018, str. 813.

14 U praksi je primjenjivano pravilo temeljem kojeg je u procjeni slavenske pripadnosti birača procjenjivan stupanj akulturacije birača, i to ponajviše činjenica kojim jezikom se osoba služi u privatnom i javnom životu. Ukoliko je osoba upotrebljavala hrvatski, srpski, odnosno slovenski jezik onda je bila uvrštavana u popis birača, dok su u suprotnom slučaju birači brisani iz izbornih listina. Geiger, V., Nijemci u Đakovu i Đakovštini, Hrvatski institut za povijest, Zagreb, 2001, str. 97-98.

Usp. Geiger, op. cit. u bilj. 14, str. 93; Izbori su provedeni 28. studenog 1920. godine, a provedbeni propis relevantan za primjenu mirovnog ugovora sklopljenog s Austrijom donesen je, s barem četiri mjeseca zakašnjenja, tek 25. studenoga 1920. godine, dakle u vrijeme kad su popisi birača već sastavljeni. Vidi Uredbu o stjecanju i gubitku državljanstva Kraljevine Srba, Hrvata i Slovenaca putem opcije i molbe od 25. studenoga 1920. godine (dalje u radu: Uredba o stjecanju i gubitku državljanstva), u: Pirkmajer, O., Zakon o državljanstvu sa tumačenjem, Izdavačka knjižara Gece Kona, Beograd, 1929, str. 244-266.

16 O tome da su Česi i Slovaci na tim izborima imali biračko pravo, iako neki od njih nisu bili i državljani Kraljevine SHS, vidi: Dugački, V., "Postat ćemo Jugoslaveni ili ćemo ostati ono što jesmo": češka manjina i pitanje državljanstva u međuratnoj Jugoslaviji, Radovi Zavoda za znanstvenoistraživački i umjetnički rad u Bjelovaru, br. 9, 2015, str. 88-89.; Dugački, V., „Manjinska posla“ Političko organiziranje češke i slovačke manjine na izborima za Ustavotvornu skupštinu 1920. godine, Časopis za suvremenu povijest, vol. 44., br. 2, 2012, str. 405.; O ograničavanju prava glasa Židovima, Nijemcima i Mađarima vidi: Banac, I., Nacionalno pitanje u Jugoslaviji: porijeklo, povijest, politika, Globus, Zagreb, 1988, str. 361.

17 Tako je primjerice Njemačka stranka osnovana tek kasnije te su prvi izbori za Narodnu skupštinu na kojima je sudjelovala bili izbori provedeni 1923. godine. Rezultat Njemačke stranke na izborima vidi u: Čulinović, F., Jugoslavija između dva rata, knjiga I, Jugoslavenska akademija znanosti i umjetnosti, Zagreb, 1961, str. 406, 409.

18 Slovačka narodna stranka obnovila je svoj rad 10. studenoga 1918. godine, dok su Česi svoju prvu stranku pod imenom „Čehoslovačka napredna seljačka stranka“ osnovali neposredno uoči izbora za Ustavotvornu skupštinu, 10. listopada 1920. godine. Dugački, „Manjinska posla“op. cit. u bilj. 16, str. 392, 399. 
Ovakvo definiranje ovlaštenika političkih prava imalo je značajan utjecaj na izborni rezultat u pojedinim dijelovima zemlje. Tako su velikim dijelom zbog toga, u Baranji, Banatu i Bačkoj te u nekim dijelovima Slavonije vrlo usko pobijedili radikali. ${ }^{20}$ Riječ je o multietničkom području u kojem bi mogućnosti radikala, ali i demokrata, bile manje da su pravo glasa imali i pripadnici neslavenskih manjina. ${ }^{21}$

Na ovom mjestu valja još napomenuti da je definiranje ovlaštenika političkih prava na temelju nacionalne pripadnosti, a ne državljanstva, bilo protivno Ugovoru o zaštiti manjina koji je Kraljevini SHS nametnut na Pariškoj mirovnoj konferenciji, ${ }^{22}$ a koji je dio pravnog poretka Kraljevine SHS postao objavom u Službenom listu 19. lipnja 1920. godine, dakle u vrijeme prije održavanja izbora za Ustavotvornu skupštinu. ${ }^{23}$ Članak 9. izbornog zakona za Ustavotvornu skupštinu bio je u naime u suprotnosti s člankom 7. Zakona o zaštiti manjina koji je propisivao načelo jednakosti državljana te pravo svih državljana da uživaju građanska i politička prava neovisno od njihove rasne i vjerske pripadnosti i jezika kojim govore. ${ }^{24}$

\subsection{NEJEDNAKOST U BIRAČKOM PRAVU}

Bitno obilježje pravnog poretka Kraljevine SHS u prvim godinama bila je nejednakost birača. U osnovi, radi se o problemu nejednakosti birača prema izbornom zakonu za Ustavotvornu skupštinu iz 1920. godine. Temelj nejednakosti ogledao se u činjenici da je broj glasova potrebnih za osvajanje mandata u Ustavotvornoj skupštini značajno varirao. Tako je jednog zastupnika u Banatu, Bačkoj i Baranji birao 3301 registrirani birač, dok je najviše registriranih birača potrebnih za izbor jednog zastupnika bilo u Dalmaciji i to 8092. U tom rasponu nalazile su se sve ostale pokrajine pa je tako u Crnoj Gori jednog zastupnika biralo 4337 birača, u Sloveniji je zastupnika birao 5381 birač, u Metohiji, Kosovu i Sandžaku zastupnika je biralo 5600 birača, u Srbiji je zastupnika biralo 5662 birača, Makedoniji 5990, u Hrvatskoj i Slavoniji 6849, dok je u Bosni i Hercegovini jednog zastupnika biralo 7495 registriranih birača. Osim ovih nejednakosti, izborni

20 Banac, op. cit. u bilj. 16, str. 361.

21 Iz rada Vladimira Geigera je vidljivo da su značajnu ulogu prilikom sastavljanja izbornih listina pa i brisanja Neslavena iz popisa birača na području Đakova imali pristaše Demokratske stranke. Geiger, op. cit. u bilj. 14, str. 94-97.

22 Banac, op. cit. u bilj. 16, str. 361; Propisi o zaštiti manjina bili su integralni dio mirovnih ugovora koje su sklopile Austrija, Mađarska, Kraljevina SHS, Bugarska, Rumunjska, Grčka, Poljska i Čehoslovačka. Vidi više u: Grizo, M., The Versailles System of Peace Treaties and the Minority Protection in Southeast Europe - The Bulgarian-Greek Convention for the Exchange of Population of 1919, Annals Fac. L. Belgrade - Belgrade Law Review, Godina LVIII , br. 3, 2010, str. 68-72.; Fink, C., The Paris Peace Conference and the Question of Minority Rights, Peace \& Change, vol. 21, br. 3, 1996, str. 280-283; Iako je prvotno odbila pristati na odredbe ugovora o zaštiti manjina, Kraljevina SHS je nakon političkih pritisaka ipak prihvatila ovu regulativu. Djokić, D. Makers of the Modern World. The peace conferences of 1919-23 and their aftermath. Pašić and Trumbić. The Kingdom of Serbs, Croats and Slovenes. Haus Publishing, London, 2010, str. 128, 131-134; O razilaženjima u delegaciji Kraljevine SHS kao i o prvotnom nepotpisivanju mirovnog ugovora s Austrijom vidi i: Mitrović, A., Jugoslavija na konferenciji mira 1919-1920, Zavod za izdavanje udžbenika Socijalističke Republike Srbije, Beograd, 1968, str. 200-206.

Ovakvo definiranje političke zajednice imalo je izvorište u liberalnim načelima te nastojanju glavnih protagonista Pariške mirovne konferencije da osiguraju oblikovanje novoosnovanih država na temelju načela jednakosti državljana te da, s obzirom na prisutnu primjenu etničkih kriterija u praksi te konstituiranje tih država kao nacionalnih država, osiguraju zaštitu pripadnika nacionalnih manjina te ujedno i lojalnost tih manjina prema vlastima tih država. Riga, L., Kennedy, J., Tolerant majorities, loyal minorities and "ethnic reversals": constructing minority rights at Versailles 1919, Nations and Nationalism, Vol. 15, No. 3, 2009 , str. 465 . 
sustav je odražavao i nejednakosti između velikih gradova i ostatka zemlje pri čemu je manji broj glasača za osvajanje jednog mandata bio potreban u velikim gradovima, Ljubljani, Zagrebu i Beogradu. Pri tome je i tu dolazilo do nejednakosti pa je tako u gradu Zagrebu jedan zastupnik dolazio na 4954 birača dok je u Beogradu jedan zastupnik biran na 2737 birača. ${ }^{25}$

Ovako skrojen izborni sustav u osnovi je privilegirao Narodnu radikalnu stranku te druge stranke koje su se zalagale za unitarno uređenje države. Tako je Narodnoj radikalnoj stranci za jedan mandat u Narodnoj skupštini bilo potrebno 3127 glasova, dok je Radićevoj Hrvatskoj pučkoj seljačkoj stranci kao predstavnici federalističkog koncepta državnog uređenja za jedan mandat bilo potrebno 4611 glasova. Krojenje izbora bilo je utoliko značajnije ako imamo u vidu činjenicu da je broj glasova koje su dobile stranke koje su se zalagale za unitarizam, odnosno za federalno uređenje države bio gotovo podjednak. ${ }^{26}$ Međutim, za odnos snaga u Ustavotvornoj skupštini ključna je bila upravo spomenuta nejednakost birača te bitno različit broj glasova potreban za osvajanje mandata. Ilustrativna je u tom smislu usporedba ukupnog broja glasova koje su na izborima postigle Narodna radikalna stranka i Hrvatska pučka seljačka stranka te broj osvojenih mandata u Ustavotvornoj skupštini. Naime, Narodna radikalna stranka je dobila 284575 glasova, dok je Hrvatska pučka seljačka stranka dobila 230590 glasova. ${ }^{27}$ Izrazimo li glasove Narodne radikalne stranke indeksom 100, broj glasova koje je dobila Hrvatska pučka seljačka stranka bio bi 81,03. Ukupni broj mandata koje je na izborima ostvarila Narodna radikalna stranka bio je 91, dok je Hrvatska pučka seljačka stranka osvojila 50 mandata. ${ }^{28}$ Izrazimo li broj mandata Narodne radikalne stranke indeksom 100, broj osvojenih mandata Hrvatske pučke seljačke stranke bio bi otprilike 55. Dakle, vidljiva je značajna nadzastupljenost Narodne radikalne stranke u odnosu prema Hrvatskoj pučkoj seljačkoj stranci.

Značajna okolnost koja je doprinijela privilegiranju centralistički usmjerenih stranaka prilikom raspodjele mandata bila je i različita veličina izbornih jedinica u pojedinim dijelovima Kraljevine SHS te činjenica da je kao osnova za oblikovanje izbornih jedinica upotrebljavan popis stanovništva iz 1910. godine. ${ }^{29}$

Prethodne napomene o nejednakom biračkom pravu imaju za cilj ukazati na različito definiranje tog političkog prava u različitim dijelovima države. Iako je dio odgovora na pitanje o nejednakom biračkom pravu moguće tražiti u interesima Narodne radikalne stranke, pa i činjenici da je ta stranka imala najjače uporište upravo na području bivše Kraljevine Srbije, ovdje treba istaknuti i neke druge argumente koji su prevladavali u političkom diskursu u dvadesetim godinama, a tiču se prije svega konstatacije da je Kraljevina Srbija podnijela najveće ljudske žrtve za oslobođenje „prečanskih krajeva“. Mišljenja smo da je očitu nejednakost biračkog prava koja je provedena izbornim zakonom iz 1920. godine moguće sagledavati i kao vid svojevrsne „kompenzacije“ za žrtve koje je Kraljevina Srbija podnijela u ratu. Da je „trgovanja žrtvama“ Srbije bilo, vidljivo je i na nekim drugim primjerima. Ilustrativni primjeri su izrazito nepovoljna konverzija

\footnotetext{
25 Banac, op. cit. u bilj. 16, str. 362-363.

26 Ibid, str. 364, 366.

27 Čulinović, op. cit. u bilj. 17, str. 309.

28 Ibid. 
prilikom zamjene kruna u dinare koja je značajno pogodila upravo bivša austrougarska područja, kao i porezna nejednakost te veća porezna obaveza nametnuta tim područjima. ${ }^{30}$

\subsection{AUTORITARNOST I OGRANIČAVANJE POLITIČKIH PRAVA}

Autoritaran odnos vlasti prema građanima i politike ograničavanja političkih prava bile su vidljive već po osnivanju Kraljevine SHS. ${ }^{31}$ Autoritarno postupanje vlasti vidljivo je i na primjeru izbora provedenih 1920. godine u postupcima kojima je ograničavana izborna promidžba stranaka koje su zagovarale republički oblik vladavine i federalno državno uređenje. Ilustrativan je u tom smislu odnos vlasti prema Hrvatskoj pučkoj seljačkoj stranci tijekom 1920. godine te zatvaranje Stjepana Radića i njegovo puštanje tek na dan izbora, 28. studenoga 1920. godine. ${ }^{32}$

Odnos vlasti prema aktivnostima Komunističke partije bio je pak bitno određen činjenicom da je ta stranka s obzirom na kritiku građanskog društva ocijenjena kao antisustavna. Stoga, iako je Komunistička partija Jugoslavije prvotno tolerirana te joj je dopušten rad kao i natjecanje na lokalnim izborima i izborima za Ustavotvornu skupštinu 1920. godine, nakon dobrih rezultata na lokalnim izborima tijekom proljeća i ljeta 1920. godine te nakon dobrih rezultata na izborima za Ustavotvornu skupštinu na kojima je bila četvrta po broju osvojenih glasova te treća po broju osvojenih zastupničkih mjesta, Vlada Kraljevine SHS je značajno zaoštrila politiku prema toj stranci te je potkraj 1920. godine donijela Obznanu. Obznanom su komunistima ograničena prava na političko udruživanje te su zabranjeni komunistički tisak i javni skupovi. Prilikom donošenja Obznane Ministarski savjet je obrazložio njeno donošenje potencijalnim opasnostima od širenja komunizma, opasnostima u pogledu javne sigurnosti te sličnim mjerama koje su poduzele zapadne zemlje. ${ }^{33} \mathrm{Na}$ taj je način komunistima bitno ograničeno političko djelovanje te su im ujedno u bitnoj mjeri ograničena politička prava. Ipak, Obznanom Komunistička partija još uvijek nije stavljena u potpunosti izvan zakona budući da tim aktom nije zabranjen rad komunističkim zastupnicima u Skupštini.

\subsection{PRAVNI PARTIKULARIZAM I POLITIČKA PRAVA}

Bitno obilježje razvoja političkih prava u vremenu do donošenja Ustava Kraljevine SHS bio je pravni partikularizam. U Kraljevini SHS bilo je naime šest pravnih područja i to slo-

30 O nepovoljnoj konverziji kruna u dinare, poreznoj nejednakosti te trgovanju sa žrtvama Srbije vidi: Bičanić, Rudolf. Ekonomska podloga hrvatskog pitanja i drugi radovi. Pravni fakultet u Zagrebu, Organizator, Zagreb, 1995, str. 41-55.

31 Vidi primjerice: Janjatović, B., Hrvatska 1928.-1934. godine: vrijeme organiziranih političkih ubojstava, Povijesni prilozi, vol. 13, 1994, str. 220-225.; Janjatović, B., Represija spram hrvatskih seljaka 1918.-1921. Časopis za suvremenu povijest, god. 25, br. 1, 1993, str. 30-42.; Omerović, E. S., Elementi represije u radu Narodnog vijeća Slovenaca, Hrvata i Srba za Bosnu i Hercegovinu i Narodne vlade za Bosnu i Hercegovinu, Historijska traganja, god. 3, 2009, str. 202-210.

32 Matković, H., Stjepan Radić u izbornoj 1920. godini, Časopis za suvremenu povijest, god. 24, br. 3, 1993, str. 78-85. 
vensko-dalmatinsko, hrvatsko-slavonsko, bivše ugarsko, bosanskohercegovačko, srbijansko i crnogorsko pravno područje. ${ }^{34}$

Na svakom od pravnih područja u vrijeme ujedinjenja važila je različita regulativa političkih prava te različit stupanj razvijenosti tih prava. Ne ulazeći dublje u problematiku, valja tek ilustrativno uputiti na temeljne razlike između pojedinih pravnih područja. Tako je slovensko-dalmatinsko područje, prethodno u sastavu Austrije, baštinilo relativno liberalan odnos vlasti prema pravima građana, uključujući ovdje i politička prava. Za razvoj političkih prava od iznimne je važnosti temeljni državni zakon o pravima građana iz 1867 . godine. ${ }^{35}$ Tim zakonom propisana je lista prava građana, među kojima su bila i politička prava. ${ }^{36}$ Značajno obilježje područja bila je i tradicija izbora za pokrajinska predstavnička tijela i za Carevinsko vijeće te potkraj razdoblja vrlo široko definirano biračko pravo za muške državljane. ${ }^{37}$ Razvoj političkih prava na hrvatsko-slavonskom području karakteriziralo je, do izborne reforme 1910. godine, vrlo ograničeno pravo glasa za muškarce kojim je bilo obuhvaćeno tek oko $2 \%$ stanovništva. Tek je izbornom reformom iz 1910. godine to izborno pravo prošireno na $8 \%$ stanovništva. ${ }^{38}$ Pravo na javno okupljanje regulirano je gotovo u potpunosti prema austrijskom uzoru. ${ }^{39}$ Značajno je napomenuti da su mogućnosti ostvarenja političkih prava u političkoj i upravnopravnoj praksi nagodbenog razdoblja značajno varirale. ${ }^{40}$ Bivše ugarsko područje karakterizirale su do 1918. godine specifičnosti odnosa Mađara kao dominantne nacije i pojedinih narodnosti. ${ }^{41}$ Bitno obilježje ugarskog pravnog sustava bilo je relativno usko definirano biračko pravo te činjenica da nije postajala zakonska regulativa o pravu na javno okupljanje, nego je to pravo bilo regulirano vladinim uredbama. ${ }^{42}$ Bosanskohercegovačko područje karakterizirala je tradicija vrlo ograničenih političkih prava te dodjela značajnijih političkih prava bosanskohercegovačkim pripadnicima tek Ustavom iz 1910. godine. ${ }^{43}$ Za politička prava na području bivše Kraljevine Srbije te Crne Gore značajni su Ustavi kojima je građanima zajamčen niz političkih prava. ${ }^{44} \mathrm{Uz}$ to, za razvoj političkih prava i u Srbiji i u Crnoj Gori vrlo su značajne bile i odredbe ugovora iz 1878. kojima je tim državama nametnuta obveza poštivanja građanskih i političkih

34 Čulinović, F., Državnopravni razvitak Jugoslavije, Školska knjiga, Zagreb, 1963, 224-227; Pavlović, M., Problem izjednačenja zakona u Kraljevini Srba, Hrvata i Slovenaca / Jugoslaviji, Zbornik Pravnog fakulteta u Zagrebu, god. 68, br. 3-4, 2018, str. 494.

35 Temeljni zakon o pravima građana vidi u: Bernatzik, E., Die österreichischen Verfassungsgesetze, Manzsche k. u. k. Hof-Verlagsund Universitätsbuchhandlung, Wien, 1911, str. 422-427.

36 Čepulo, D., Prava građana i moderne institucije: europska i hrvatska pravna tradicija, Pravni fakultet Sveučilišta u Zagrebu, 2003, str. 117.

37 Ibid. str. 90.

38 Ibid, str. 106.

39 Ibid, str. 127-128.

40 Za ograničenja slobode tiska vidi primjerice: Ibid, str. 153-156.

41 Macartney C. A, The Habsburg Empire 1790-1918, Weidenfeld and Nicolson, 1971, str. 721-734.

42 Čepulo, op. cit. u bilj. 36, str. 90, 120.

43 Vidi Ustav Bosne i Hercegovine iz 1910. godine. Bavčić, U., (ur.) Bosanski ustav, fototip izdanja iz 1910. godine, Muslimanski glas, Sarajevo, 1991. Dostupno na: https://www.scribd.com/doc/117687515/Bosanski-ustav-1910 (pristup 12.12.2018.)

44 Vidi 2. dio Ustava Kraljevine Srbije iz 1903. godine naslovljen „Ustavna prava srpskih građana“. Ustav za Kraljevinu Srbiju iz 1903. godine. Državna štamparija Kraljevine Srbije, Krf, 1916, str. 4-8; Usp. 14. dio Ustava Crne Gore iz 1905. godine naslovljen „Ustavna prava crnogorskih državljana“. Tekst Ustava je dostupan na: http://www.montenegrina.net/pages/pages1/istorija/ dokumenti/Ustav\%20Crne\%20Gore\%20iz\%201905.pdf (pristup 1.1. 2018.). 
prava pripadnicima vjerskih manjina te obveza poštivanja načela jednakosti državljana. ${ }^{45}$ Opće biračko pravo nije ni ovdje postojalo. Tako je primjerice u Srbiji, na izborima 1912. godine biračko pravo imalo svega $22 \%$ stanovnika. ${ }^{46}$

Različita regulativa o političkim pravima, kao i različita praksa ostvarenja tih prava te specifično pravno-kulturno okruženje u kojem su se ta prava razvijala na svakom od pojedinih pravnih područja značajno su otežavala unifikaciju regulative o političkim pravima. ${ }^{47}$ Tako je pravni partikularizam bio važno obilježje pravnog sustava Kraljevine SHS u prvim godinama njenog postojanja. Pri tome je važno napomenuti da su vlasti Kraljevine SHS u određenoj mjeri taj partikularizam dalje održavale. Primjer za ovo jesu posebni propisi kojima je regulirano biračko pravo na lokalnim izbornima na pojedinim pravnim područjima. Tako su tijekom 1919. godine donesene uredbe kojima su posebno regulirani lokalni izbori i biračko pravo na hrvatsko-slavonskom području. ${ }^{48}$ Drugi primjer jesu posebne odredbe Izbornog zakona iz 1920. godine kojima su pojedini elementi biračkog prava regulirani posebno za područja bivše Austro-Ugarske Monarhije, a posebno za područja bivših kraljevina Srbije i Crne Gore. Ovdje se naime radilo o definiranju kruga osoba koje nemaju biračko pravo zbog toga što su osuđene za pojedina zakonom točno određena kažnjiva ponašanja. ${ }^{49}$

Iako je pravni partikularizam bio značajno obilježje pravnog poretka, valja istaknuti i neke elemente koji govore u prilog izgradnji jedinstvene regulative o političkim pravima. Ovdje svakako treba spomenuti izborni zakon kojima su regulirani izbori za Ustavotvornu skupštinu 1920. godine, a koji iako sadrži neke specifičnosti, u osnovi ipak predstavlja jedinstvenu regulativu za čitavu Kraljevinu SHS. Primjer unifikacije je i Obznana budući da je važila na čitavom teritoriju Kraljevine SHS.

\section{POLITIČKA PRAVA U VIDOVDANSKOM USTAVU}

Ustav Kraljevine SHS, usvojen 28. lipnja 1921. godine, sadrži značajne odredbe o političkim pravima i to o biračkom pravu, pravu na javno okupljanje, pravu na političko udruživanje i slobodu tiska. Ustav regulira aktivno biračko pravo na način ga imaju svi muškarci koji su navršili 21 godinu uz pretpostavku državljanstva Kraljevine SHS (čl. 70. Ustava Kraljevine SHS). Pasivno biračko pravo Ustav daje muškim državljanima koji su navršili 30 godina pod pretpostavkom da „govore i pišu narodnim jezikom“ (čl. 72. Ustava Kraljevine SHS). Uz navedeno, da bi osoba imala pasivno biračko pravo trebala je biti državljanin po rođenju. Ukoliko je

$45 \mathrm{Su}, \mathrm{A} .$, Woodrow Wilson and the Origins of the International Law of Religious Freedom, Journal of the History of International Law, vol. 15, no. 2, 2013, str. 259; Mazur Kumrić, N., Europski sustav zaštite prava manjina uz poseban osvrt na Vijeće Europe i Organizaciju za sigurnost i suradnju u Europi, Školska knjiga, Zagreb, 2017, str. 125.

46 Gligorijevć, op. cit. u bilj. 13, str. 67.

47 O problemu unifikacije prava u Kraljevini SHS/Jugoslaviji s obzirom na različite tradicije vidi: Pavlović, op. cit. u bilj. 34, str. 494495, 513-515. i dalje.

48 Uredba o izboru gradskih zastupstava za gradove Hrvatske i Slavonije, u: Zbornikzakona i naredaba valjanih za Hrvatsku i Slavoniju, godina 1919, Kr. zemaljska tiskara, Zagreb, 1920, str. 267-271; Uredba o izboru općinskih odbora za upravne općine Hrvatske i Slavonije, u: Zbornik zakona i naredaba valjanih za Hrvatsku i Slavoniju, godina 1919, Kr. zemaljska tiskara, Zagreb, 1920, str. 274-280. 
pak osoba stekla državljanstvo naturalizacijom, ona je imala pasivno biračko pravo samo ako je bila „narodnosti srpsko-hrvatsko-slovenačke“, dok su naturalizirani pripadnici ostalih narodnosti stjecali pasivno biračko pravo tek nakon proteka roka od deset godina od provedene naturalizacije (čl. 72. Ustava Kraljevine SHS). Ustavom je državljanima zajamčena sloboda tiska (čl. 13. Ustava Kraljevine SHS), dok kao ograničenje te slobode Ustav navodi slučajeve kad se tiskom izazivaju „mržnja protiv države kao cjeline, vjerski ili plemenski razdor“ te slučajeve kad se tiskom „poziva građane da silom mijenjaju ustav ili zemaljske zakone“ (čl. 138. Ustava Kraljevine SHS). Ustavom se građanima jamče i pravo udruživanja te pravo na javno okupljanje uz Ustavom nametnutu obvezu organizatorima javnog skupa na otvorenom da taj skup prijave nadležnim tijelima najmanje 24 sati prije održavanja skupa (čl. 14. Ustava Kraljevine SHS). Ustav zabranjuje dolazak na javne skupove s oružjem (čl. 14. Ustava Kraljevine SHS). Ustavom je dozvoljeno pravo udruživanja pod pretpostavkom da se radi o udruženju čiji ciljevi nisu „po zakonu kažnjivi“ (čl. 14. Ustava Kraljevine SHS). Ustavom je predviđeno ograničavanje prava udruživanja i javnog okupljanja u slučajevima izvanrednih stanja (čl. 127. Ustava Kraljevine SHS).

Osnovno je usmjerenje Ustava s obzirom na reguliranje političkih prava bilo liberalno. Pri tome, normativno gledano, odredbe Ustava Kraljevine SHS, u usporedbi s dotadašnjim stanjem, predstavljaju napredak. Ustav je propisao vrlo široku listu političkih prava te stoga što je potvrdio opće biračko pravo za muškarce starije od 21 godine uz zakonodavcu ostavljenu mogućnost da biračko pravo dobiju i žene (čl. 70. Ustava Kraljevine SHS). Ustav je sukladan i Zakonu o zaštiti manjina budući da političku zajednicu oblikuje na načelu narodnog suvereniteta te na načelu jednakosti svih državljana Kraljevine SHS neovisno od nacionalne pripadnosti. Odstupanje od Zakona o zaštiti manjina je tek odredba Ustava kojom je pasivno biračko pravo ograničeno naturaliziranim državljanima na rok od deset godina, ukoliko po narodnosti nisu bili Srbi, Hrvati ili Slovenci. Ustavom su unificirane neke odredbe o političkim pravima čime su osnaženi temelji jedinstvenog ustavnopravnog poretka, dok je daljnja unifikacija ostavljena zakonodavcu.

\section{TEMELJNA OBILJEŽJA POLITIČKIH PRAVA NAKON DONOŠENJA VIDOVDANSKOG USTAVA}

Analiza odnosa nacionalne pripadnosti i načina na koji su definirani ovlaštenici političkih prava u vremenu nakon donošenja Ustava pokazuje značajna odstupanja u usporedbi s prethodno primijenjenim modelom. Osnovno odstupanje ogleda se u činjenici da su s obzirom na protek rokova za opciju te s obzirom na Zakon o zaštiti manjina, otpale mogućnosti definiranja ovlaštenika političkih prava na temelju nacionalne pripadnosti (Usp. čl. 7. Zakona o zaštiti manjina). Od tada pa nadalje politička prava više nisu bila ograničavana državljanima s pravom opcije. Rokovi za opciju bili su relativno kratki, za neke opcije 6, a za neke 12 mjeseci, pa su istekli još tijekom 1922. godine..$^{50}$ Kako navodi profesor zagrebačkog Pravnog fakulteta

50 Rok za opciju na temelju ranije zavičajnosti bio je 12 mjeseci, dok je rok za opciju na temelju nacionalne pripadnosti bio 6 mjeseci. Usp. čl. 6. i 12. Uredbe o stjecanju i gubitku državljanstva; Usp. čl. 5. i 10. Naredbe o postupanju pri stjecanju i gubitku državljanstva Kraljevine Srba, Hrvata i Slovenaca putem opcije i molbe od 30. kolovoza 1921. godine. Tekst Naredbe vidi u: Pirkmajer, op. cit. u bilj. 15, str. 283-301. 
Ladislav Polić, ograničavanje biračkog prava državljanima Kraljevine SHS koji nisu Srbi, Hrvati ili Slovenci nakon proteka roka za opciju u suprotnosti je i s čl. 4. Ustava o jednakosti državljana pred zakonom i člana 7. Ugovora o zaštiti manjina koji zabranjuje diskriminaciju državljana s obzirom na rasu, jezik ili vjeru. ${ }^{51}$ To je pak omogućilo Nijemcima, Mađarima i Rumunjima da osnuju svoje političke stranke. ${ }^{52}$

Ipak, treba napomenuti da je veza između nacionalne pripadnosti i oblikovanja političke zajednice i dalje postojala, iako nije bila vidljiva u Ustavu niti u izbornom zakonu. Naime, ta veza je vidljiva u nacionalnoj određenosti državljanstva koje je bilo temeljna pretpostavka definiranja ovlaštenika političkih prava. Nacionalna određenost državljanstva bila je tako vidljiva u predmetima utvrđivanja državljanstva i stjecanja državljanstva Kraljevine SHS. ${ }^{53}$

Analiziramo li problem nejednakosti u političkim pravima, poglavito nejednakosti u biračkom pravu, možemo vidjeti da su određene nejednakosti, prisutne do donošenja Vidovdanskog ustava bile prisutne i dalje. Osnovu za takve nejednakosti pružio je i sam Vidovdanski ustav koji je usprkos pravilu o jednakosti biračkog prava u osnovi predvidio zadržavanje izbornog zakona iz 1920. godine (usp. čl. 141. Ustava Kraljevine SHS). Takva odredba dala je osnovu vladajućoj većini da usvoji samo minimalne izmjene zakona tijekom 1922. godine uz zadržavanje nejednakosti u pogledu biračkog prava i na izborima tijekom 1923. godine. $\mathrm{Na}$ tim izborima kao osnova za raspodjelu mandata korišteni popisi stanovništva iz 1910. godine iako je novi popis stanovništva proveden još 1921. godine. Opozicioni Hrvatski blok je tome oštro prigovarao ističući da primjena popisa stanovništva iz 1910. godine ujedno znači „dodjelu mandata za šest stotina tisuća poginulih Srba“" ${ }^{54}$ Ipak, nejednakosti biračkog prava bile su zadržane i kasnije. ${ }^{55}$ Razloge za ovakvo održavanje nejednakosti biračkih prava treba tražiti u dubljim neravnotežama između bivših austrougarskih krajeva i Kraljevine Srbije koje su bile vidljive i na drugim poljima, pa tako primjerice i u nejednakoj poreznoj obavezi koja je bila znatno viša za stanovnike koji su živjeli na područjima bivše Austro-Ugarske Monarhije. Pri tome su i ove porezne nejednakosti, slično kao i nejednakosti u biračkom pravu, opravdavane žrtvama koje je Srbija imala u ratu. ${ }^{56}$

Autoritaran odnos vlasti prema političkim pravima bio je također bitna značajka razvoja političkih prava u razdoblju važenja Vidovdanskog ustava. Procesi vidljivi već ranije, u prvim godinama nove države, i to u praksama prema opoziciji i posebno federalistički usmjerenim političarima, kao i odnos vlasti prema Komunističkoj partiji vidljiv na primjeru Obznane, u razdoblju nakon donošenja Vidovdanskog ustava bitno su oblikovani Zakonom o zaštiti javne

51 Polić, L., Izborni zakon prema ustavu i prema praksi, Mjesečnik: glasilo pravničkoga društva, broj 4. i 5, travanj i svibanj 1923, str. 150 .

52 Janjetović, op. cit. u bilj. 19, str. 70.

53 Kosnica, op. cit. u bilj. 13, str. 818-823; Kosnica, I., Odnos državljanstva i nacionalne pripadnosti u Kraljevini SHS/Jugoslaviji. Zbornik Pravnog fakulteta u Zagrebu, god. 68, br. 1, 2018, str. 69-76; Vidi i etnički određene odredbe Zakona o državljanstvu Kraljevine Srba, Hrvata i Slovenaca od 21. rujna 1928. godine. Primjerice čl. 12. st. 4. kojim je predviđena olakšana naturalizacija Srba, Hrvata i Slovenaca. Navedenu odredbu s komentarom vidi u: Cavalieri, C., Propisi o državljanstvu Kraljevine Srba, Hrvata $i$ Slovenaca, Vlastita naklada, Zagreb, 1929, str. 28-36.

54 Gligorijević, op. cit. u bilj. 13, str. 130; Čulinović, op. cit. u bilj. 17, str. 404.

55 Balkovec, B., Izborno zakonodavstvo prve jugoslavenske države (1918. - 1941.), Časopis za suvremenu povijest, god. 48, br. 1, 2016, str. 205-206. 
bezbednosti i poretka u državi donesenim u kolovozu 1921. godine (dalje u radu: ZZJBPD). ${ }^{57}$ Ovim zakonom, koji je kolokvijalno nazvan Zakon o zaštiti države, djelatnost Komunističke partije Jugoslavije je u potpunosti proglašena protuzakonitom, a komunistička stranka je isključena iz Narodne skupštine. ${ }^{58}$ Prema odredbama toga zakona pripadnici Komunističke partije i bilo kojeg zakonom zabranjenog udruženja, nisu mogli obnašati nikakvu javnu dužnost niti biti izabrani za zastupnike u političkim tijelima, a zabrana zapošljavanja odnosila se i na „službenike privatnih ustanova koje imaju izvjesne naročite privilegije od strane države, a koji službenici pripadaju komunističkoj stranci“ (čl. 18. ZZJBPD). Zakonom o zaštiti države djelomično je regulirana i materija javnog okupljanja na način da su zabranjena javna okupljanja u otvorenim ili zatvorenim prostorima na kojima sudionici nose zastave i razne transparente kojima je cilj stvaranje javnog mišljenja o nužnosti zamjene postojećeg poretka „putem prevrata, rušenjem privatne svojine ili uništenjem javnoga mira“ (čl. 12. ZZJBPD). Nadalje, ovim zakonom je također zabranjeno i samo prisustvovanje takvim javnim skupovima (čl. 13. ZZJBPD). Zakonom o zaštiti države zabranjeno je sudjelovanje u udruženjima kojima je cilj širenje komunizma, odnosno u drugim udruženjima kojima je cilj doći na vlast neparlamentarnim putem (čl. 1. st. 2. ZZJBPD). Zakonom o zaštiti države vlasti su u bitnoj mjeri ograničile slobodu tiska štiteći se prije svega od komunističke propagande, ali i svake druge propagande koja bi imala za cilj nasilnu promjenu javnog poretka (čl. 1. st. 1. ZZJBPD).

Autoritarnost režima vidljiva je i na temelju analize visine propisanih sankcija. Pri tome je najveća težina dana pravu na političko udruživanje i pravu na slobodu tiska. Zakonom o zaštiti države tako je zabranjeno već sudjelovanje u udruženjima kojima je cilj širenje komunizma, odnosno drugim udruženjima kojima je cilj doći na vlast neparlamentarnim putem te je već za sudjelovanje u radu takvih udruženja propisana smrtna kazna, odnosno kazna zatvora do 20 godina (čl. 1. st. 2. i čl. 2. ZZJBPD). Zakonom o zaštiti države, vlasti su u bitnoj mjeri ograničile slobodu tiska štiteći se prije svega od komunističke propagande, ali i od svake druge propagande koja bi imala zacilj nasilnu promjenu javnog poretka budući da je za ova kažnjiva ponašanja propisana smrtna kazna, odnosno kazna zatvora do 20 godina (čl. 1. st. 1. i čl. 2. ZZJBPD). Normativno ograničenje autoritarnog karaktera ovoga propisa ogledalo se u činjenici da su dopuštena udruživanje pa i sloboda tiska koja su usmjerena na nenasilnu i parlamentarnu promjenu nekih temeljnih obilježja javnog poretka što je u osnovi moglo uključivati i federalizam.

Iako je Zakon o zaštiti države u osnovi bio usmjeren na djelatnost komunističke partije te se u tom s smislu nastavljao na tradiciju Obznane, valja reći da su pojedine odredbe u tom zakonu bile vrlo široko definirane. Imajući u vidu već ranije vidljive autoritarne prakse i odnos vlasti prema političkim pravima građana, odredbe Zakona o zaštiti države otvarale su latentnu mogućnost primjene toga zakona i na neke druge, ponajprije federalistički usmjerene građane. Tako je stalna opasnost primjene toga zakona prijetila Hrvatskoj republikanskoj seljačkoj stranci, do čega je u konačnici i došlo tijekom 1924. godine. ${ }^{59}$

Autoritarnost vlasti u odnosu prema oporbi vrlo je vidljiva i na primjeru zabrane raznih tiskovina u razdoblju od 1921. do 1929. godine. Podatci za grad Zagreb, koji je ujedno bio najjače oporbeno središte, pokazuju da su zabranjivani mahom oporbeni listovi, i to ponajvi-

Zakon o zaštiti javne bezbednosti i poretka u državi, Izdavačka knjižarnica Gece Kona, 3. izdanje, Beograd, 1927.

58 Gligorijević, op. cit. u bilj. 13, str. 300. 
še listovi koje su izdavali Komunistička partija Jugoslavije, Hrvatska republikanska seljačka stranka, Hrvatska zajednica, odnosno Hrvatska federalistička seljačka stranka. ${ }^{60}$ Najčešći razlozi zabrane listova bili su objava članaka koji „su posredno pozivali građane da silom mijenjaju Ustav i zemaljske zakone“, zatim članaka koji „su vršili vjerski ili plemenski razdor“, članaka koji „su izazivali mržnju protiv države kao cjeline“ te članci koji „su vrijeđali kralja ili člana kraljevskog doma, stranog državnog poglavara ili člana skupštine“. ${ }^{1}$

Pravni partikularizam kao značajno obilježje pravnog sustava u Kraljevini SHS u predustavnom razdoblju, bio je vidljiv i u vremenu nakon donošenja Vidovdanskog ustava, iako u nešto manjoj mjeri. Ključne točke i osnovicu jedinstva pravnog sustava u pogledu reguliranja političkih prava u vremenu nakon donošenja Ustava činile su upravo odredbe Vidovdanskog ustava te odredbe Zakona o zaštiti države. Značajan jedinstveni propis kojim je regulirano biračko pravo na izborima za Narodnu skupštinu bio je izborni zakon iz 1922. godine. Pored navedenog, u ovom razdoblju je 1925. godine donesen i jedinstveni Zakon o tisku iz 1925. godine. ${ }^{62} \mathrm{~S}$ druge strane, partikularizam je vidljiv u nepostojanju zakona o pravu na javno okupljanje i udruživanje te u posebnim propisima kojima je regulirano biračko pravo na lokalnim izborima, a koji su vrijedili za pojedina pravna područja. Tako je primjerice još tijekom 1927. godine donesen propis kojim je regulirano biračko pravo na lokalnim izborima na području Hrvatske i Slavonije. ${ }^{63}$ Pri tome treba napomenuti da propisi donošeni za pojedina pravna područja nisu bili samo formalnopravno različiti nego su sadržavali i značajne materijalno-pravne razlike. ${ }^{64}$

Analiza razvoja političkih prava u razdoblju važenja Vidovdanskog ustava pokazuje svojevrstan kontinuitet u procesima koji su bili vidljivi već u prvim godinama postojanja nove države. Pri tome je taj kontinuitet ponegdje lakše uočljiv dok je ponegdje vidljiv tek posredno. Tako je kontinuitet posredno vidljiv u odnosu nacionalne pripadnosti i političkih prava, u određenoj je mjeri vidljiv i u pravnom partikularizmu, dok je najvidljiviji u pitanjima nejednakosti biračkog prava te u autoritarnom odnosu vlasti prema političkim pravima građana.

\section{ZAKLJUČAK}

Provedena analiza temeljnih obilježja političkih prava u Kraljevini SHS ukazuje na postojanje četiri temeljna obilježja, a to su značajna veza između nacionalne pripadnosti i oblikovanja političke zajednice, zatim nejednakost biračkog prava, autoritaran odnos vlasti prema političkim pravima te pravni partikularizam. Dinamiku i razvoj tih obilježja u pravnom poretku

60 Šubić Kovačević, I.,. Kontrola i zabrana oporbenog zagrebačkog tiska 1921. - 1929, Radovi Zavoda za hrvatsku povijest Filozofskoga fakulteta Sveučilišta u Zagrebu, god. 48, br. 1, 2016, str. 336.

61 Ibid, str. 343.

62 Ibid, str. 331.

63 Krbek, I., Izborni red za odbore seoskih upravnih općina u Hrvatskoj i Slavoniji sa Sremom prema odredbi od 31. V. 1927, Naklada Gospodarskih novina, Zagreb, 1927, str. 14-51.

64 Ovu problematiku detaljno je u disertaciji obradio Anto Milušić. Milušić, A., Izborni sistemi za lokalna predstavnička tijela u staroj Jugoslaviji s osvrtom na jugoslavenske zemlje prije njihova državnog ujedinjenja 1918, doktorska disertacija (neobjavljeno), Pravni fakultet Sveučilišta u Zagrebu, Zagreb, 1976, str. 236-384. 
Kraljevine SHS analizirali smo u prvim godinama postojanja Kraljevine SHS, zatim kroz donošenje Ustava Kraljevine SHS tijekom 1921. godine te u razdoblju nakon donošenja Ustava pa sve do ukidanja Ustava i proglašenja Šestosiječanjske diktature. Osnovni je zaključak rada da su trendovi razvoja, vidljivi u prvim formativnim godinama Kraljevine SHS, bili u značajnoj mjeri prisutni i dalje, iako uz određene modifikacije.

Tako analiza odnosa između nacionalne pripadnosti i biračkog prava pokazuje značajno odstupanje od prvotnog obrasca uvjetovano prije svega nametnutim propisom o zaštiti manjina koji je zabranjivao diskriminaciju državljana s obzirom na nacionalnu pripadnost. Ipak, i na ovom području je očita veza između nacionalne pripadnosti i uspostave političke zajednice vidljiva ponajviše u politikama utvrđivanja i stjecanja državljanstva koje su bile značajno nacionalno određene. Analiza nejednakosti biračkog prava pokazuje pak da su značajne nejednakosti u pogledu biračkog prava, uspostavljene izbornim zakonom iz 1920. godine, usprkos odredbi Ustava o načelnoj jednakosti biračkog prava, bile održavane i u kasnijem razdoblju. Autoritaran odnos vlasti prema političkim pravima građana pokazuje također izrazit kontinuitet pa su tako osnovne smjernice razvoja vidljive u predustavnom razdoblju bile prisutne i dalje, u razdoblju nakon donošenja Ustava, usprkos samom tekstu Ustava koji je politička prava regulirao sukladno liberalnoj tradiciji. Analiza razvoja političkih prava kroz prizmu partikularizma ukazuje na postepenu unifikaciju prava te na značajne korake u tom smjeru kroz donošenje Ustava te Zakona o zaštiti države koji je sadržavao i odredbe o političkim pravima građana. Ipak, i ovdje su vidljivi tek relativni uspjesi vlasti primjerice u donošenju Zakona o tisku tijekom 1925. godine, uz još uvijek vidljive centrifugalne tendencije pa i donošenja posebnih propisa za pojedina pravna područja poput propisa kojima su regulirani lokalni izbori.

Izložena obilježja razvoja, upućuju na zaključak na niz nejednakosti pa i partikularizama u definiranju onoga što se u modernoj znanosti naziva political citizenship, odnosno što smo mi preveli sintagmom ovlaštenici političkih prava. Ove nejednakosti i partikularizmi iako su dijelom bili uvjetovani i tradicijom, u određenoj su mjeri bili promovirani i od vladajuće elite. U tom smislu ilustrativan je primjer nejednakosti biračkog prava između pojedinih dijelova države. Takve nejednakosti stvorile su svojevrsnu pukotinu u konceptu političkih prava te su djelovale dezintegrirajuće.

\section{LITERATURA}

1. Balkovec, B., Izborno zakonodavstvo prve jugoslavenske države (1918.-1941.), Časopis za suvremenu povijest, god. 48, br. 1, 2016, str. 197-216.

2. Banac, I., Nacionalno pitanje u Jugoslaviji: porijeklo, povijest, politika, Globus, Zagreb, 1988.

3. Bara, M., Trianon, podjela svjetova i bačko-baranjski Hrvati, Povećalo: časopis za povijest i prosudbe o povijesnoj zbilji, god. 4-7, 2012, str. 24-42.

4. Bernatzik, E., Die österreichischen Verfassungsgesetze, Manzsche k. u. k. Hof-Verlags- und Universitätsbuchhandlung, Wien, 1911.

5. Bičanić, R., Ekonomska podloga hrvatskog pitanja i drugi radovi. Pravni fakultet u Zagrebu, Organizator, Zagreb, 1995.

6. Bös, M., The Legal Construction of Membership: Nationality Law in Germany and the United 
States, Program of the Study of Germany and Europe. Working Paper Series No. 005, str. 5-7., dostupno na: http://aei.pitt.edu/63702/1/PSGE_00_5.pdf (pristup: 9. 12. 2018.)

7. Budisavljević, S., Stvaranje države Srba, Hrvata i Slovenaca: povodom četrdesetgodišnjice jugoslavenskog ujedinjenja, Jugoslavenska akademija znanosti i umjetnosti, Zagreb, 1958.

8. Cavalieri, C., Propisi o državljanstvu Kraljevine Srba, Hrvata i Slovenaca, Vlastita naklada, Zagreb, 1929.

9. Čepulo, D., Prava građana i moderne institucije: europska i hrvatska pravna tradicija, Pravni fakultet Sveučilišta u Zagrebu, 2003.

10. Čulinović, F., Jugoslavija između dva rata, knjiga I., Jugoslavenska akademija znanosti i umjetnosti, Zagreb, 1961.

11. Čulinović, F., Državnopravni razvitak Jugoslavije, Školska knjiga, Zagreb, 1963.

12. Djokić, D. Makers of the Modern World. The peace conferences of 1919-23 and their aftermath. Pašić and Trumbić. The Kingdom of Serbs, Croats and Slovenes, Haus Publishing, London, 2010.

13. Dugački, V., „Manjinska posla“ - Političko organiziranje češke i slovačke manjine na izborima za Ustavotvornu skupštinu 1920. godine, Časopis za suvremenu povijest, vol. 44, br. 2, 2012, str. 389-413.

14. Dugački, V., "Postat ćemo Jugoslaveni ili ćemo ostati ono što jesmo": češka manjina i pitanje državljanstva u međuratnoj Jugoslaviji, Radovi Zavoda za znanstvenoistraživački i umjetnički rad u Bjelovaru, sv. 9, 2015, str. 83-104.

15. Fahrmeir, A., Citizenship: The Rise and Fall of a Modern Concept, Yale University Press, New Haven and London, 2007.

16. Fink, C., The Paris Peace Conference and the Question of Minority Rights, Peace \& Change, vol. 21, no. 3, 1996, str. 273-288.

17. Geiger, V., Nijemci u Đakovu i Đakovštini, Hrvatski institut za povijest, Zagreb, 2001.

18. Gligorijevć, B., Parlament i političke stranke u Jugoslaviji (1919-1929), Institut za suvremenu historiju, Narodna knjiga, Beograd, 1979.

19. Goldstein, I., Hrvatska 1918.-2008., EPH Liber, Zagreb, 2008.

20. Grizo, M., The Versailles System of Peace Treaties and the Minority Protection in Southeast Europe - The Bulgarian-Greek Convention for the Exchange of Population of 1919, 2010 Annals Fac. L. Belgrade Belgrade Law Review, god. 58, br. 3, 2010, str. 67-81.

21. Janjatović, B., Hrvatska 1928.-1934. godine: vrijeme organiziranih političkih ubojstava, Povijesni prilozi, vol. 13, 1994, str. 219-244.

22. Janjatović, B., Represija spram hrvatskih seljaka 1918.-1921., Časopis za suvremenu povijest, god. 25, br. 1, 1993, str. 25-43.

23. Janjetović, Z., Deca careva, pastorčad kraljeva: Nacionalne manjine u Jugoslaviji, INIS, Beograd, 2005.

24. Janjetović, Z., National Minorities in Yugoslavia 1918-1941, Review of Croatian History, god. 8, br. 1, 2012, str. 61-75.

25. Joppke, C., Transformation of Citizenship: Status, Rights, Identity, Citizenship Studies, vol. 11, no.1, 2007, str. 37-48.

26. Kosnica, I., Definiranje državljanskog korpusa na hrvatsko-slavonskom području u Kraljevini SHS / Jugoslaviji, Zbornik Pravnog fakulteta Sveučilišta u Rijeci, god. 39, br. 2, 2018, str. 809-832.

27. Kosnica, I., Odnos državljanstva i nacionalne pripadnosti u Kraljevini SHS/Jugoslaviji, Zbornik Pravnog fakulteta u Zagrebu, god. 68, br. 1, 2018, str. 61-83.

28. Krbek, I., Izborni red za odbore seoskih upravnih općina u Hrvatskoj i Slavoniji sa Sremom prema odredbi od 31. V. 1927., Naklada Gospodarskih novina, Zagreb, 1927. 
29. Macartney C. A., The Habsburg Empire 1790-1918, Weidenfeld and Nicolson, 1971.

30. Marshall, T.H., Class, Citizenship and Social Development, Doubleday and Company, Anchor Books. New York, 1965.

31. Matijević, Z., U sjeni dvaju orlova: Prilozi crkveno-nacionalnoj povijesti Hrvata u prvim desetljećima 20. stoljeća, Golden marketing-Tehnička knjiga, Zagreb, 2005.

32. Matković, H., Stjepan Radić u izbornoj 1920. godini, Časopis za suvremenu povijest, god. 24, br. 3, 1993, str. 75-86.

33. Mazur Kumrić, N., Europski sustav zaštite prava manjina uz poseban osvrt na Vijeće Europe i Organizaciju za sigurnost i suradnju u Europi, Školska knjiga, Zagreb, 2017.

34. Mesić, M., Globalizacija i građansko-državljanska prava, Politička misao, vol. 45, br. 1, 2008, str. 71-92.

35. Milušić, A., Izborni sistemi za lokalna predstavnička tijela u staroj Jugoslaviji s osvrtom na jugoslavenske zemlje prije njihova državnog ujedinjenja 1918., Pravni fakultet Sveučilišta u Zagrebu (neobjavljeno), Zagreb, 1976.

36. Mitrović, A., Jugoslavija na konferenciji mira 1919-1920., Zavod za izdavanje udžbenika Socijalističke Republike Srbije, Beograd, 1968.

37. Omerović, E. S., Elementi represije u radu Narodnog vijeća Slovenaca, Hrvata i Srba za Bosnu i Hercegovinu i Narodne vlade za Bosnu i Hercegovinu, Historijska traganja, god 3, 2009, str. 183-213.

38. Pavlović, M., Problem izjednačenja zakona u Kraljevini Srba, Hrvata i Slovenaca / Jugoslaviji, Zbornik Pravnog fakulteta u Zagrebu, god. 68, br. 3-4, 2018, str. 493-523.

39. Pezo, V. (gl. ur.) Pravni leksikon, Leksikografski zavod „Miroslav Krleža“, Zagreb, 2007.

40. Pirkmajer, O., Zakon o državljanstvu sa tumačenjem, Izdavačka knjižara Gece Kona, Beograd, 1929.

41. Polić, L., Izborni zakon prema ustavu i prema praksi, Mjesečnik: glasilo pravničkoga društva, broj 4. i 5., travanj i svibanj 1923, str. 145-156.

42. Polić, L., O pravnim osnovima budućeg izbornoga reda, Mjesečnik: glasilo pravničkoga društva, Zagreb, br. 2, 1922, str. 49-63.

43. Riga, L., Kennedy, J., Tolerant majorities, loyal minorities and „ethnic reversals“: constructing minority rights at Versailles 1919, Nations and Nationalism, Vol. 15, No. 3, 2009, str. 461-482.

44. Su, A., Woodrow Wilson and the Origins of the International Law of Religious Freedom, Journal of the History of International Law, Vol. 15, No. 2,2013, str. 235-267.

45. Šubić Kovačević, I., Kontrola i zabrana oporbenog zagrebačkog tiska 1921. - 1929., Radovi Zavoda za hrvatsku povijest Filozofskoga fakulteta Sveučilišta u Zagrebu, god. 48, 2016, str. 329-351.

\section{IZVORI}

1. Bavčić, U., (ur.) Bosanski ustav, fototip izdanja iz 1910. godine, Muslimanski glas, Sarajevo, 1991. Dostupno na: https://www.scribd.com/doc/117687515/Bosanski-ustav-1910 (pristup 12.12.2018.)

2. Uredba o izboru gradskih zastupstva za gradove Hrvatske i Slavonije, u: Zbornik zakona i naredaba valjanih za Hrvatsku i Slavoniju, godina 1919., Kr. zemaljska tiskara, Zagreb, 1920., str. 267-271.

3. Uredba o izboru općinskih odbora za upravne općine Hrvatske i Slavonije, u: Zbornik zakona i naredaba valjanih za Hrvatsku i Slavoniju, godina 1919., Kr. zemaljska tiskara, Zagreb, 1920., str. 274-280.

4. Ustav za Kraljevinu Srbiju iz 1903. godine. Državna štamparija Kraljevine Srbije, Krf, 1916. 
5. Ustav Crne Gore iz 1905. godine. Dostupno na: http://www.montenegrina.net/pages/pages1/istorija/dokumenti/Ustav\%20Crne\%20Gore\%20iz\%201905.pdf (pristup 19. 12. 2018.).

6. Ustav Kraljevine Srba, Hrvata i Slovenaca (Obnarodovan u br. 142a „Službenih Novina“ na Vidovdan 28. lipnja 1921. god. u Beogradu), Državna štamparija Kraljevine Srba, Hrvata i Slovenaca, Beograd, 1926.

7. Zakon o izboru narodnih poslanika za ustavotvornu skupštinu Kraljevine Srba, Hrvata i Slovenaca, Naklada štamparije jugoslavenskog kompasa, Zagreb, 1920.

8. Zakon o zaštiti javne bezbednosti i poretka u državi, Izdavačka knjižarnica Gece Kona, 3. izdanje, Beograd, 1927. 
156

Ivan Kosnica*

Martina Protega*

\section{POLITICAL RIGHTS IN THE KINGDOM OF SERBS, CROATS AND SLOVENES: BASIC FEATURES DEVELOPMENT}

\section{Summary}

The authors analyse the development of basic features of political rights in the Kingdom of Serbs, Croats and Slovenes in the period from its formation in 1918 until the proclamation of the 6th January Dictatorship in 1929. The authors identify four basic features regarding development of political rights in the first years of the Kingdom and these are a strong connection of ethnicity and enjoyment of political rights, inequality of suffrage, authoritarianism in defining and implementation of political rights, and legal particularism. In addition to discussing the basic features in pre-constitutional period, the authors analyse the relation between the Constitution of 1921 and basic features of political rights. They provide arguments supporting the thesis that, despite rules contained in the Constitution, the basic features of development of political rights present in the first formative years could be detected, to a considerable degree, later in the period from 1921 until 1929, as well.

Keywords: $\quad$ political rights, suffrage, Kingdom of Serbs, Croats and Slovenes, State Protection Act

* Ivan Kosnica, PhD, Assistant professor, Chair of Croatian History of Law and State, Faculty of Law, University of Zagreb, Ćirilometodska 4, 10000 Zagreb, Republic of Croatia. Email address: ikosnica@pravo.hr ORCID: https://orcid.org/0000-00020467-6062

** Martina Protega, LLM, Public Notary Office Božo Miletić, Grge Tuškana 39, 10000 Zagreb, Republic of Croatia. Email address: martina.protega@gmail.com. ORCID: https://orcid.org/0000-0002-6892-4301 